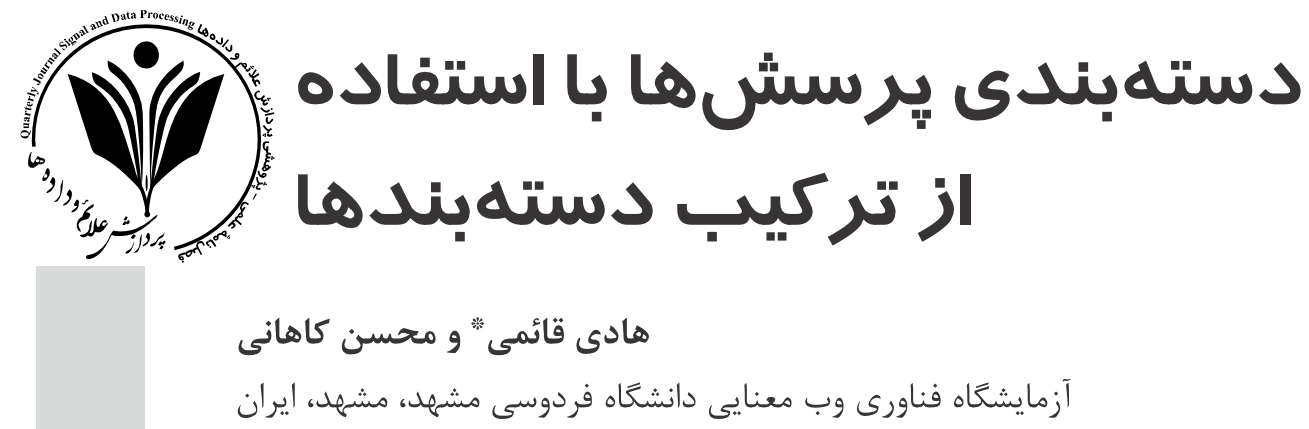

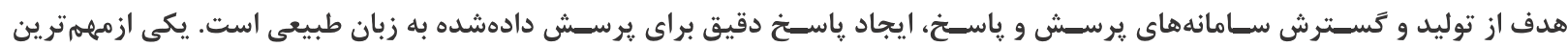

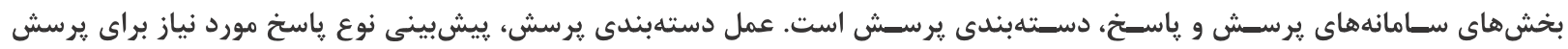

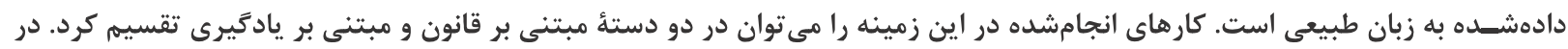

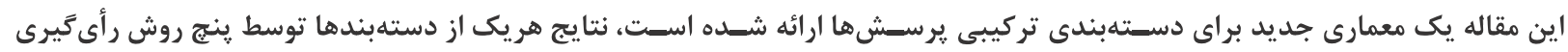

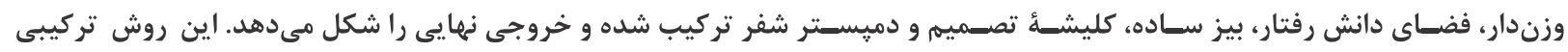

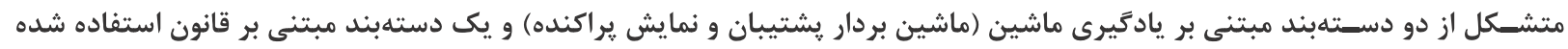

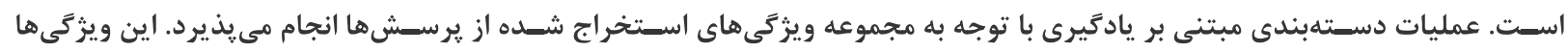

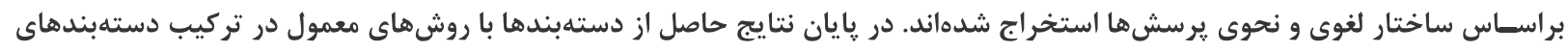

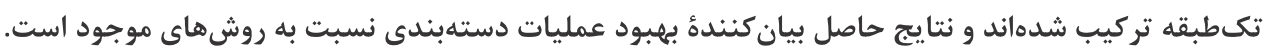
وازًَان كليدى:دستهبندى برسشها، مبتنى برقانون، مبتنى بر يادكيرى، نمايش يراكنده، ماشين بردار بشتيبان، برسشوياسخ.

\title{
Question Classification using Ensemble Classifiers
}

\author{
Hadi Ghaemi* \& Mohsen Kahani
}

Web Technology Lab. Ferdowsi University of Mashhad, Mashhad, Iran

\begin{abstract}
Question answering systems are produced and developed to provide exact answers to the question posted in natural language. One of the most important parts of question answering systems is question classification. The purpose of question classification is predicting the kind of answer needed for the question in natural language. The literature works can be categorized as rule-based and learning-based methods. This paper proposes a novel architecture for hybrid classification of questions. The results of the classifiers were combined by five methods of Weighted Voting, Behavior Knowledge space, Naive Bayes, Decision Template and Dempster-Shafer. The method uses a combination of two classifiers based on machine learning (Support Vector Machine and Sparse Representation) and one rule-based classifier. The learning-based classification uses the set of features extracted from the questions. The features are extracted on the basis of the lexical and syntactic structure of the questions. The results from the classifiers were combined by the methods that are common in the combination of one-class classifiers and the Obtained results indicate the improvement of the classification operations in comparison with the present methods.
\end{abstract}

Keywords: Question classification, Rule-based, Learning-based, Sparse Representation, Support Vector Machine, Question answering.

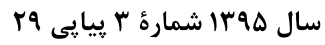


به طور كلى براى دستهبندى يرسشها سه انخيزء اصلى كاهش فضاى جستجو، مشخص كردن ياسخ و انتخاب راهبرد جسـتجو را مىتوان درنظر كرفت. در ادامه هر يك از دائ دايل توضيح داده خواهند شد.

(11)

(Table-1): Question classes [11]

\begin{tabular}{|c|c|}
\hline Coarse & Fine \\
\hline ABBR & اختصار، گسترش \\
\hline DESC & تعريف، توضيح، جَكونكَى، دليل \\
\hline ENTY & 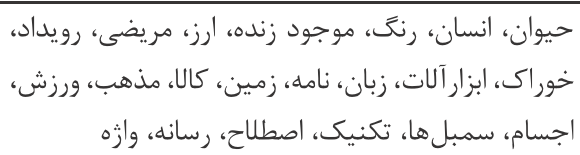 \\
\hline HUM & شخص، تفسير، گروه، عنوان \\
\hline LOC & شهر، كشور، كوه، ايالت، استان \\
\hline NUM & دمد، عدد، زمان، فاصله، يول، رتبه، درصد، مدت، سرعت، \\
\hline
\end{tabular}

كاهش فضـاى جسـتجو: با توجه به نوع طبقه مىتوان فضـاى جسـتجو را كاهش داد. به عنوان مثال با دانســن برجسب : يرسشى كه از نوع مكان است، سامانه بدنبال متنها

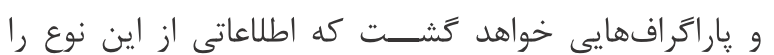
داشتهباشد.

مشخص كردن باسخ: دانستن نوع طبقه علاوهبر اينكه

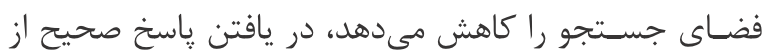

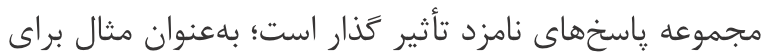
يرسش ا، برجسب تعلق گرفته از نوع مكانى است، درنتيجه از

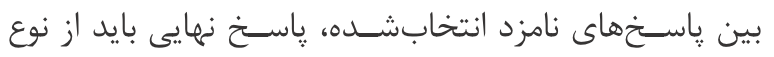
طبقه يرسش باشد.

انتخاب راهبرد جستجو: با توجه به نوع طبقه مىتوان

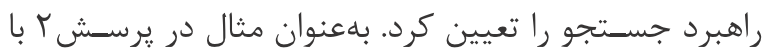

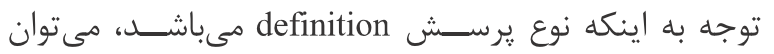

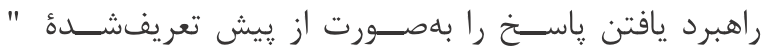
ethology is a ..."

\section{Q2: What is ethology?}

در ادامة اين مقاله ابتدا در بخش Y كارهاى انجامشده

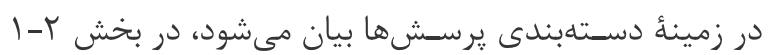

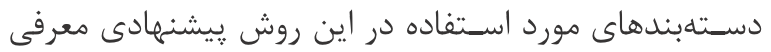

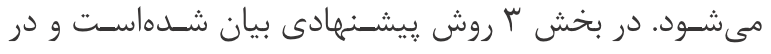

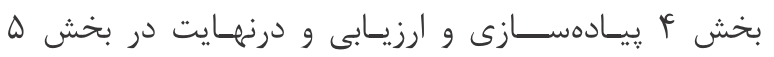

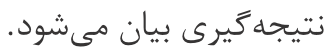

${ }^{2}$ Fine

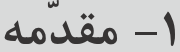

با افرايش و توسـعـ وب، نياز اسـت تا موتورهاى جسـتجو

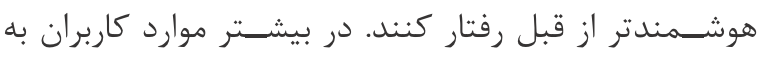
جاى فهرستى از اسناد به بخش كوجِكى از اطلاعات نياز

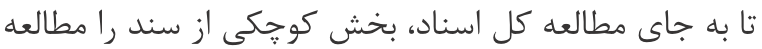

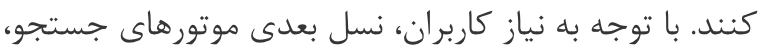

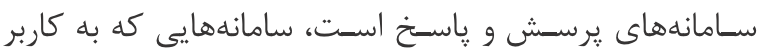
اجازه مى دهد؛ سـؤال را در سـاختار زبان طبيعى به سـامانه

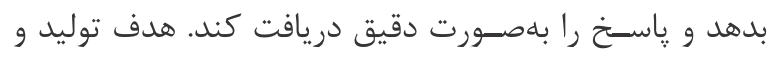

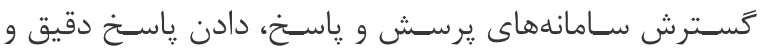
كوتاه به يرسـش داده شـده به زبان طبيعى است. دستهبندى برى يرسـش جزء مهمترين بخشهاى سامانههاى يرسش و ياسخ است.

دسـتهبندى يرسـش را مىتوان، به عمل تعيين يك مقدار منطقى به دوتايى د

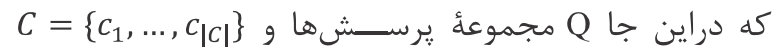

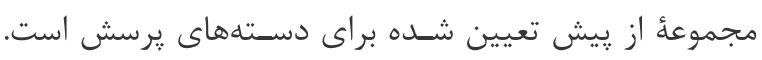
مقداردهى 》

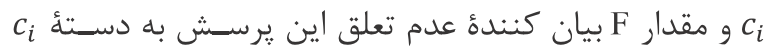

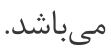
ســامانهاى يرسـش و ياســخ مختلف، معمارىهاى

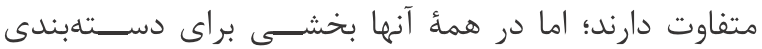

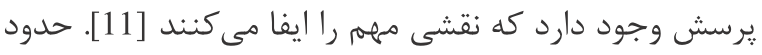

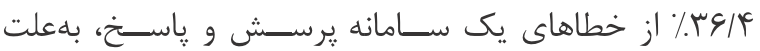

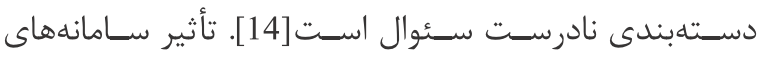
دستـبندى يرسـشها در افزايش دقت سامانههاى يرسش و

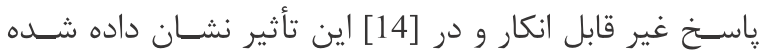

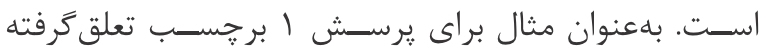
Location

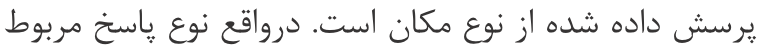

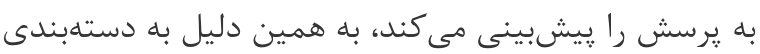

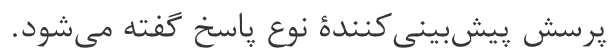

Q1: What country's capital is Tirana?

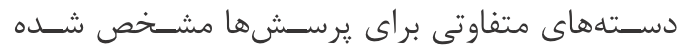

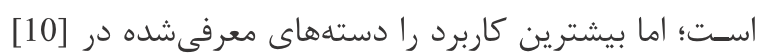
دارد، كه در آن براى برسشها دو دستهبندى ريز ' با 9 دسته

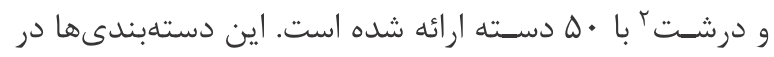

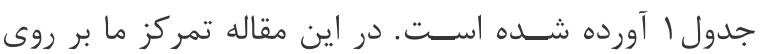
دسته ريز با و دسته است. 
بيجيده باشد؛ ساده در حد ويزگى هاى كلامى يا يِجٍيده مثل

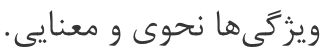
علاوهبراين، روشهاى تركيبى نيز وجود دارد كه از هر دو روش مبتنى بر يـادكيرى و مبتنى بر قانون اســـفاده

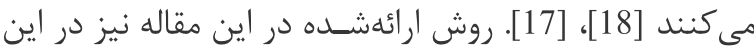

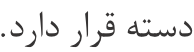

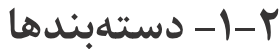
از الكَوريتمهاى دسـتهبندى مورد اسـتفاده براى دسـتهبندى برسـشها مىتوان به ماشين بردار رشتيبان [11]، شبكههاى

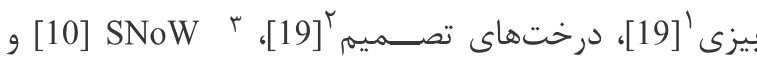

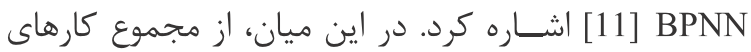

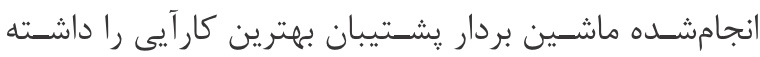

در اين مقاله از دو دسـتهبند مبتنى بر ماشــين بردار

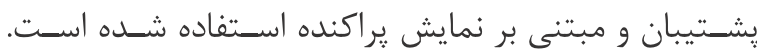

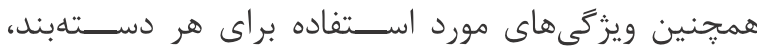
متفاوت اسـت، كه انتخاب براسـاس نتايج دستهبندها صورت

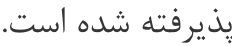

\section{|- |- |- ماشين بردار يشتيبان} ماشـين بردار يشـتيبان، با اين فرض كه دسـتهها بهصـورت

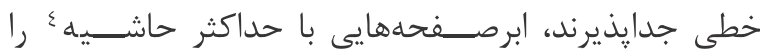
بهدست مىآورد كه دستهها را جدا كند. در دادههاى با ابعاد

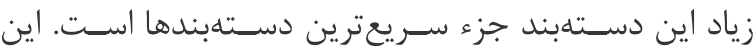

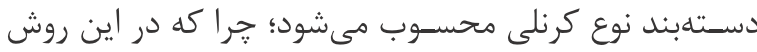
براى جداكردن دســهها، دادهها را توسـط تابعى تحت عنوان

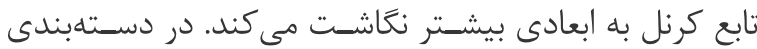

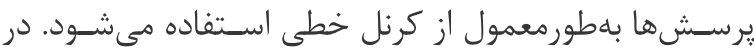
اين مقاله نيز از كرنل خطى استفاده شده است.

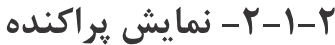

در سـامانه معادلات خطى نمايش براكنده سـامانه را فرومعين مى گويند. در اين سامانه تعداد مجهولها بيشـتر از تعداد معادلات است؛ درنتيجه بیىنهايت جواب براى آن وجود دارد. بلمنظور محدودكردن تعداد ياسخها و ارزيابى تئي مطلوبيت هر ياسـخ ممكن x، از يك تابع (x) J استفاده شده

${ }^{3}$ Sparse Network of Winnows

${ }^{4}$ Maximum margin

\section{r- مرورى بر كارهاى حذشته}

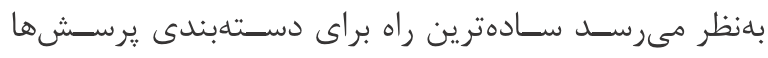
استفاده از قواعد دستنويس از بيش تعريفشده است. قوانين مورد اسـتفاده مى تواند ساده و يِيجيده باشد. ساده مثل "اكر يرسـشى كه با whom who شـروع شود به كلاس شخص

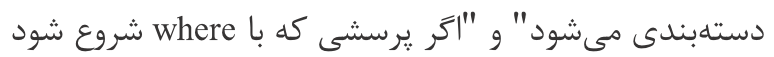
با برحسب مكانى بر هسب زده مىشود". همجنين اين قوانين

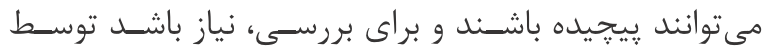

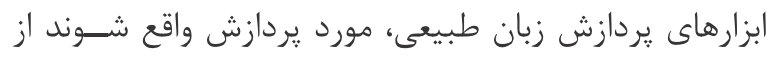
اين سامانهها مىتوان به [18] و [16] اشاره كرد. در اكثر موارد استخراج قوانين مورد استفاده بهصورت دسـتى انجام مىيذيرد [4]، [16] و [13]. اما در بعضى موارد اين قوانين بلهـورت خودكار اسـتخراج مىشوند[6]. در [6]

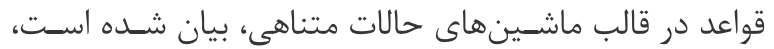
اين قواعد از روشسى خودكار و با استفاده از مثالهاى آماده، و يس از حذف ايستوازمها، و با استفاده از كليدوازهها استخراج

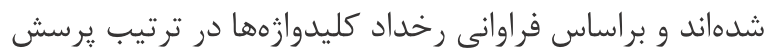

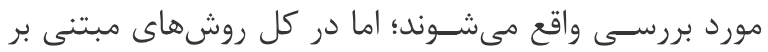

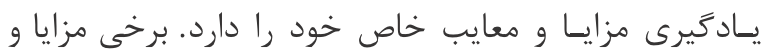
معايب اين روشها عبارتنداز: • • محاسبات سريع و ارزان دارند.

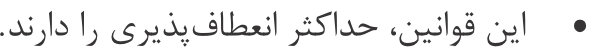

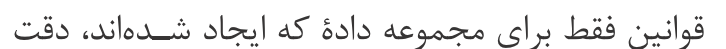

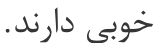
فرآيند استتخراج قوانين از يرسشها كارى خستهكننده و وقت كير و نياز به كار و صرف وقت زيادى است. تعدا قوانين استخراجى ممكن است بسيار زياد باشد، بلهنحوى كه مديريت آن مشكل شود. روشهاى مبتنى بر يادگيرى، براى بخش يادگيرى،

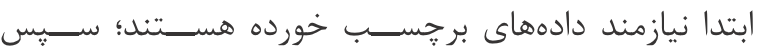
مدلهاى يادكيرى بر روى اين دادهها، آموزش داده مىشوند.

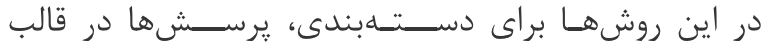

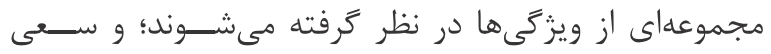

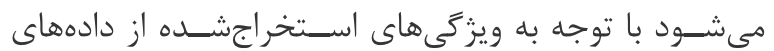

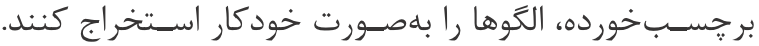
بنابراين در اين روشها انتخاب ويثگى ها و دسـتهبند اهميت

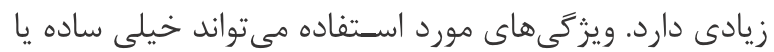

\footnotetext{
1 Naïve Bayes

2 Decision Trees
} 
يردازش متن براى نخسـتين بار و همجنين ارائٔ معمارى با استفاده از تركيب دستهبندها اشاره كرد كه باعث بهبود قابل نابل ملاحظه در نتايج نهايى شده است.

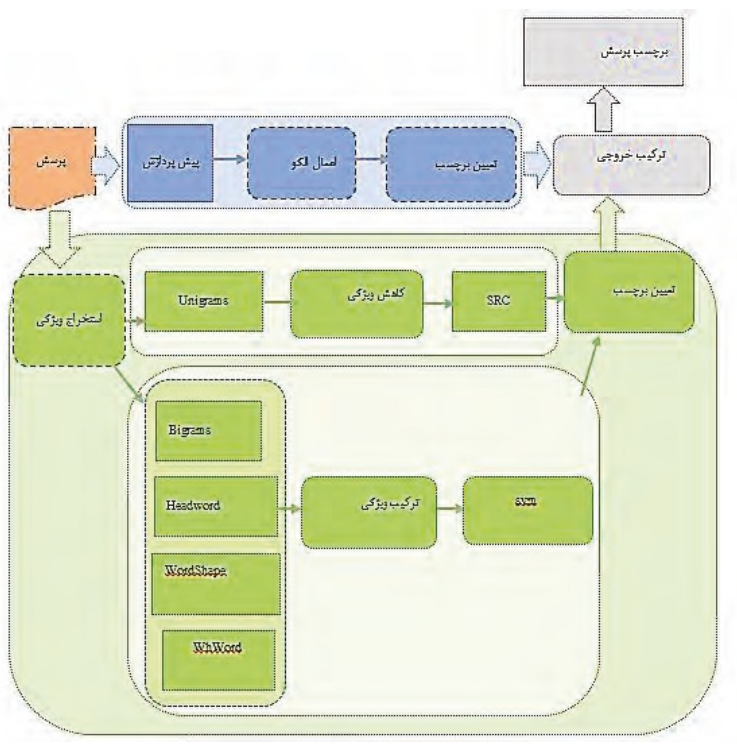

(شكل - ()): معمارى سيستم دستهبند تركيبى

(Figure-1): Architecture of Ensemble Classifier System

\section{r-1 - دستهبند مبتنى بر قانون}

براى دستهبندى مبتنى بر قانون ابتدا طى يك مرحلة

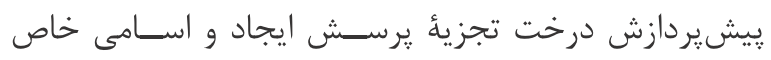

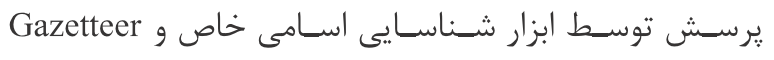

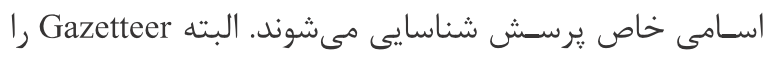

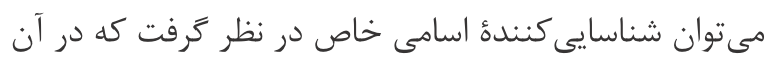

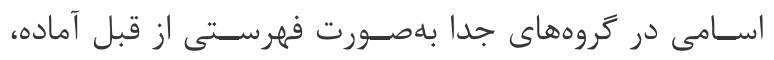

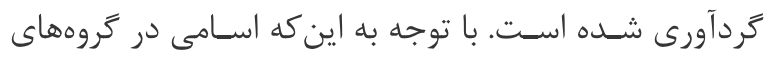

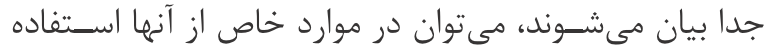

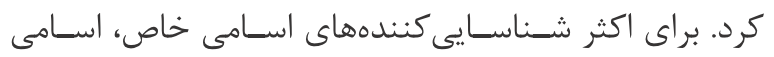

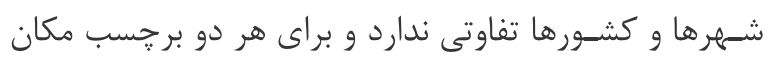

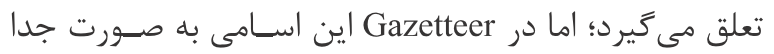

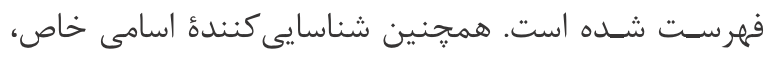

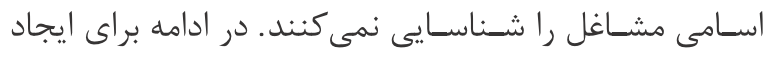

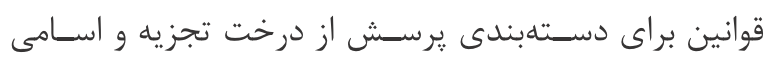
شناسايىشده استفاده مىشود. قوانين ايجادشده در دستهبند

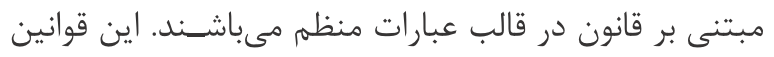

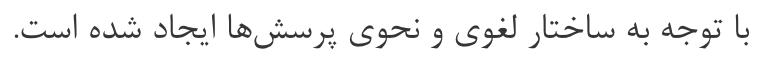

اســت و وِاســى با كمترين مقدار تابع ارزيابى، بهعنوان

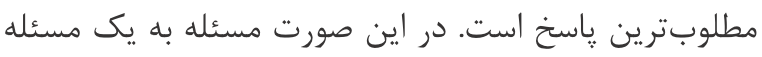

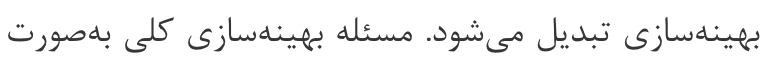
رابطؤ ا مىشود.

$\left(P_{J}\right): \min _{x} J(x)$ Subject to $b=A X$

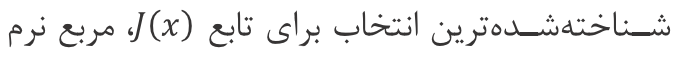

$$
\text { اقليدسى، يعنى }
$$

\section{Y-Y- دستهبندى مبتنى بر نمايش يراكنده}

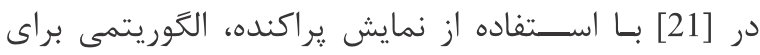

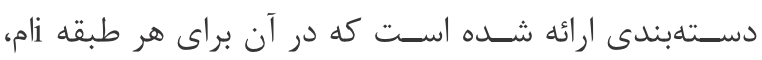

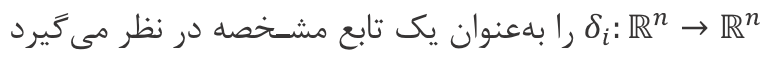

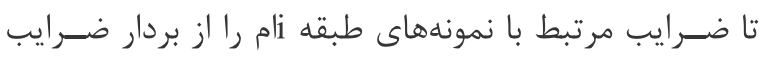
يراكنده، انتخاب كند. براى

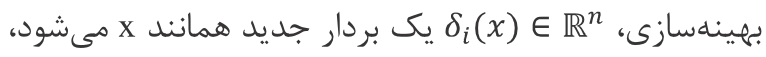

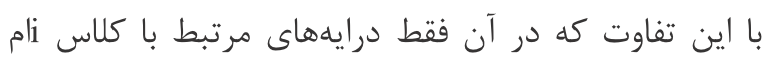

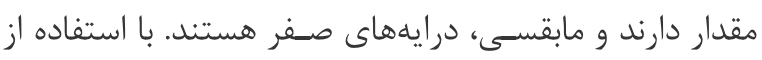

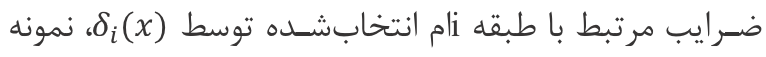
آزمون y تقريب زده مى شــود، بلهورى كه

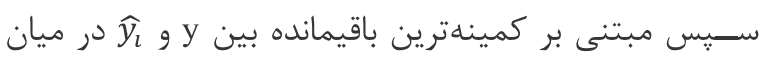

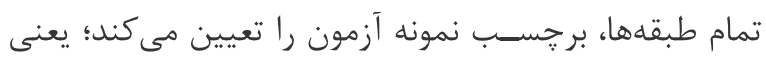

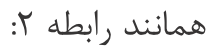

$\min _{\mathbf{i}} r_{\mathbf{i}}(\mathrm{y}) \stackrel{\circ}{=}\left\|\mathrm{y}-\mathrm{A} \delta_{\mathrm{i}}\left(\mathrm{x}_{1}\right)\right\|_{2}$

$$
\text { r- روش ييشنهادى }
$$

همان طور كه بيان شـد در روش ارائهشــده از يك دسـتهبند مبتنى بر قاعده و دو دسـتهبند مبتنى بر ياد ئيرى اسـتفاده

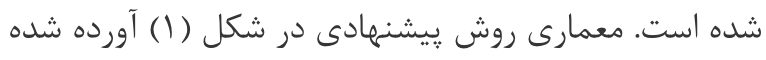

مجموعه قوانين اسـتخراجشـده در بخش مبتنى بر قانون از

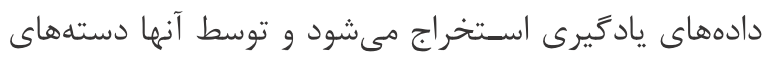

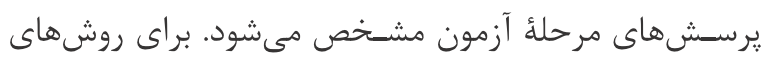

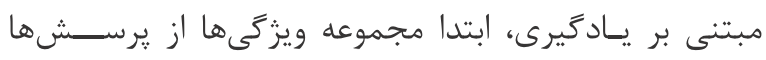

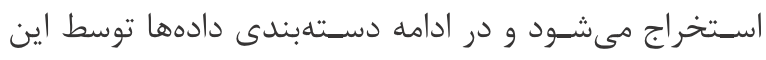

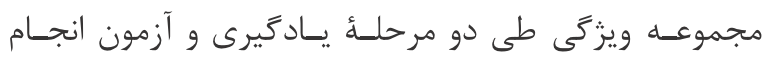

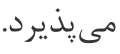
بـهـطور كلى از نوآورىهاى روش ارائهشـــه مىتوان

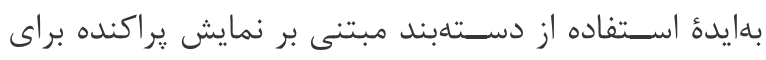


هر يك از كلمات است كه براى اين منظور نياز به استفاده از برجسـبـذار اجزاى سـخن اسـت. به عنوان مثال براى اين

$$
\text { دسته مىتوان به يرسش سه اشاره كرد: }
$$

Q3: What is the Olympic motto?

خروجى حاصـل از برجسـبـذار اجزاى كلام مربوط به اين

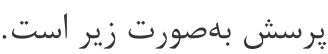

WP/What VBZ/is DT/the NNP/Olympic NN/motto.?

$$
\mathbf{x}=\left(\mathrm{x}_{1}, \mathrm{x}_{2}, \ldots, \mathrm{x}_{\mathrm{N}}\right)
$$

با توجه به خروجى برجسـبكذار اجزاى سـنن، اين

$$
\text { يرسش شرايط اعمال اين قانون را دارد. }
$$

بلهعوان مثالى ديكر ثرسـش هشــت بيان مى كند،

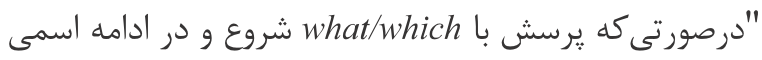

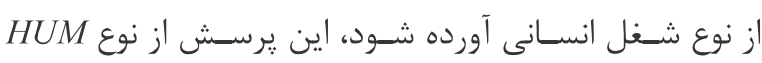
خواهد بود". براى تشـخيص اسـامى شـــل انسـانى از ابزار gazetteer

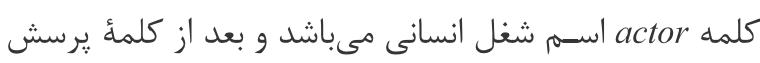
آمده است درنتيجه شرط اعمال قانون را دارا دارد.

Q4: What actor first portrayed James Bond? بايد توجه داشـت ترتيب اعمال قواعد اهميت زيادى دارد و همجنين سعى شده است تا قواعد به جهت افزايش در دقت به صـورت تركيبى از شـروط باشـــ؛ بهعنوان مثال در يرسش ينج به جهت وجود شغل انسانى ممكن است، برسش

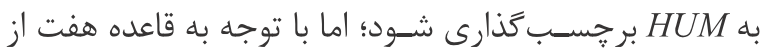

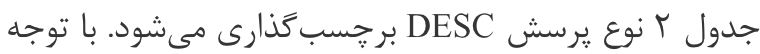
به اينكه قواعد جدول ك از قواعد با اولويت هسـتند و در در ابتدا

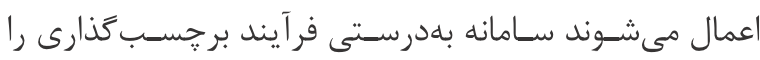

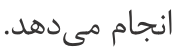

Q৯: How do doctors diagnose bone cancer?

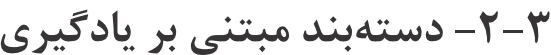
براى دســتهبند مبتنى بر يادگيرى از دســتهبند مبتنى بر نمايش يراكنده و ماشسين بردار يشـتيبان استفاده شده است.

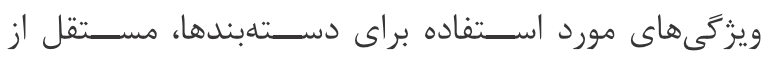

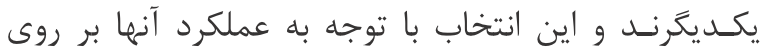

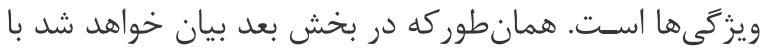

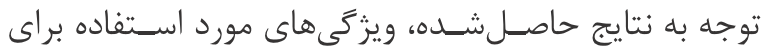

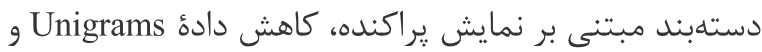

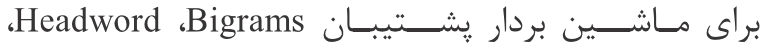
WhWord و WordShape
(جدول - ؟): برخى از قواعد مورد استفاده براى دستهبند

\begin{tabular}{|c|c|c|}
\hline & Label & Pattern \\
\hline 1 & $D E S C$ & 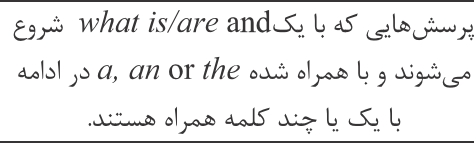 \\
\hline 2 & DESC & يرسشهايى كه با mhat do/does خاتمه مي سيابند. شروع شده و \\
\hline 3 & DESC & يرسشهايى كه با what causes/cause آغاز \\
\hline 4 & DESC & يرسشهايى كه با known for \\
\hline 5 & DESC & يرسش هايى كه با why آغاز مىشوند. \\
\hline 6 & $D E S C$ & يرسشهايى كه با what is/are آغاز مىشوند و \\
\hline 7 & $D E S C$ & 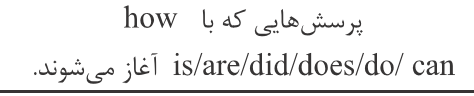 \\
\hline 8 & $H U M$ & 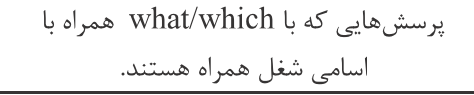 \\
\hline 9 & ENTY & يرسشهايى كه با How do you say مئاز \\
\hline 10 & $A B B R$ & 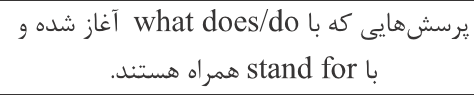 \\
\hline
\end{tabular}

مبتنى بر قاعده

(Table-2): Some of the rules used in the rule-based classifier

در جدول (T) بخشى از قوانين مورد اسـتفاده آورده

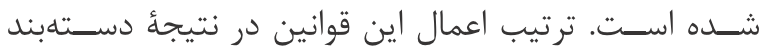

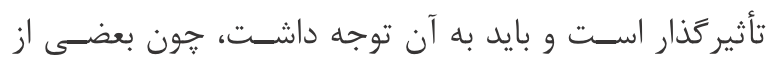
الكَوها خاص و بعضى عام هستند و قوانين خاص بايد قبل از

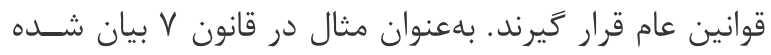

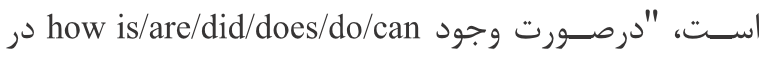
ابتداى يرسش، نوع برسش DESC خواهد بود"، همجرنين در

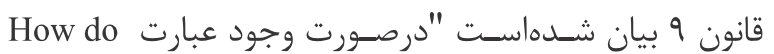

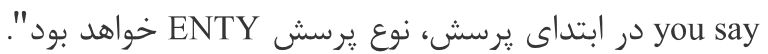

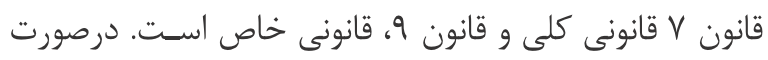

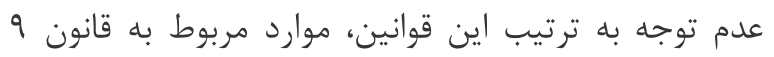
بهاشتباه توسط قانون هفت دستهبندى مى ثى تروند.

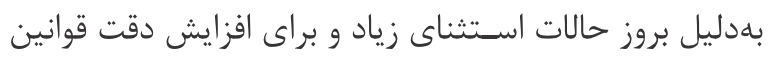

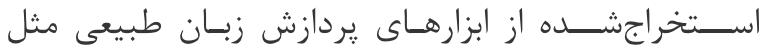

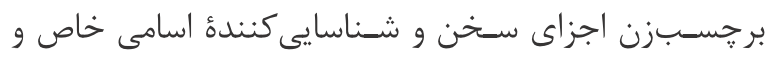
Gazetteer بهعنوان مثال، قانون شـش در حالتى رخ مىدهد كه

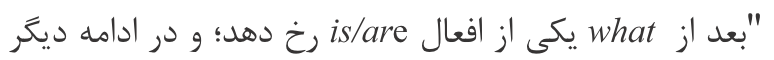

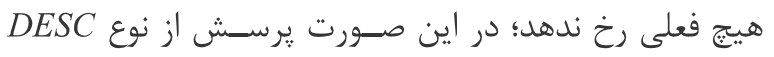

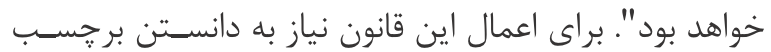


ماتريس متعامد سـطرى بوده و سـتونهاى آن بردارهاى يكه سمت راست ناميده مىشوند.

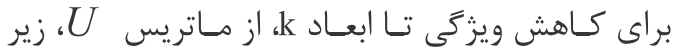
ماتريس ستون ابتدايى ماتريس ل بهصورت رابطؤ ₹ ايجاد مىشود. $R=Q^{T} U_{K}$

ابعاد اين ماتريس k>

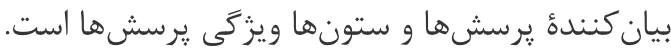

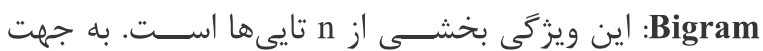
زيادبودن ابعاد اين ويزگى، فقط از دوتايى ابتدايى هر يرسـش

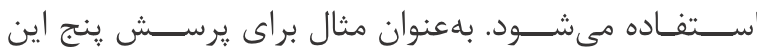
ويثز Wh-words

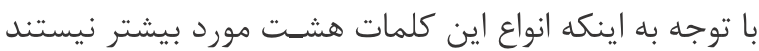
(rest, what, which, when, where, who, how, why) ابعاد اين ويزگى هشت استـت. به عنوان مثال براى يرسـش شش اين ويزگى what است.

Q6: What is the longest river in the world? Word shapes

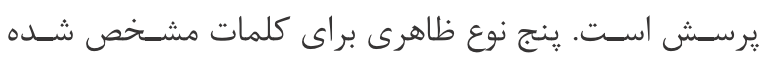
است Ather All digits, lower case, upper case, mixed اسـت. بلهعنوان مثال براى برسـش دو اين ويثَّى ها بهصورت

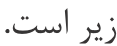

Word-shapes $=\{$ (lowercase, 4) $($ mixed, 4) $($ digit, 1) (other, 1)\}

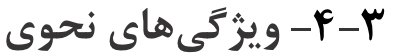

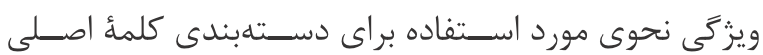

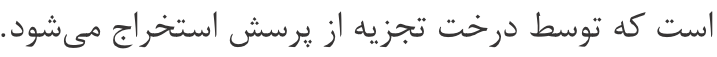

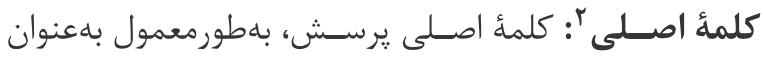
مفيدترين كلمهٔ يك يرسـش از نظر اطلاعاتى تعريف مى شود. درواقع هدف يرسش را بيان مى كند، مشخص مى كند يرسش

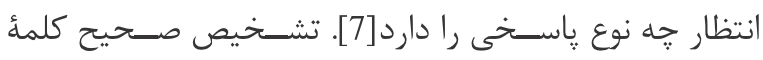

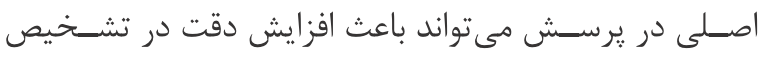

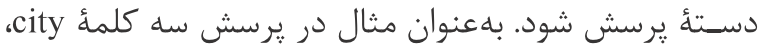
كلمؤ اصـلى ثرسـش اسـت. در اين برسـش وجود كلمه

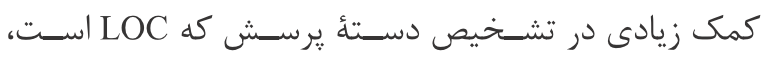

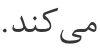

\footnotetext{
${ }^{2}$ Head Word
}

در دســـــبندى مبتنى بر يادَيرى از ويزگكىهاى

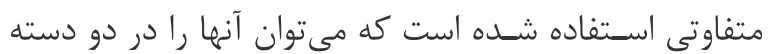
تقسيم كرد. ويزگى هاى لغوى، نحوى دستهبندى نمود.

\section{ب-r-ويزَّى هاى لغوى}

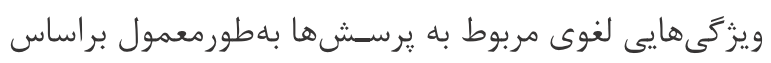

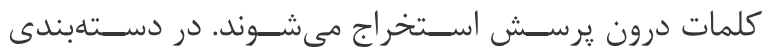

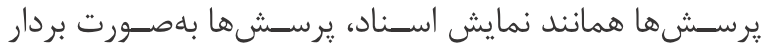

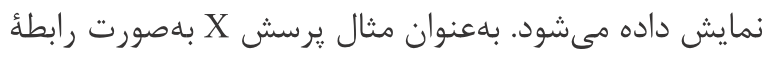

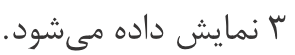

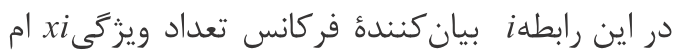
در يرسـش X و N تعدا كل ويزگى ها است. ويزگكىهاى لغوى مورد استفاده بهصورت زير است: Unigram رخداد تكتك كلمات درون برسش است. بهعنوان مثال براى يرسش ه اين مجموعه ويزگى به صورت زير مى باشد: Q5: How many Grammys did Michael Jackson win in 1983?

$x=\{($ How, 1$),($ many, 1), (Grammys, 1), (did, 1), (Michael, 1), (Jackson, 1), (win, 1), (in, 1), (1983, 1), $(?, 1)\}$

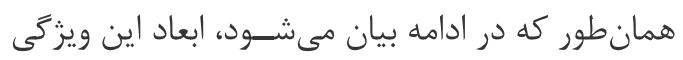

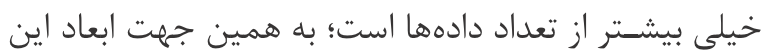
ويزَى توسط SVD كاهش داده و از كاهشيافته آن استفاده

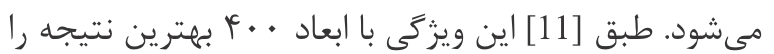

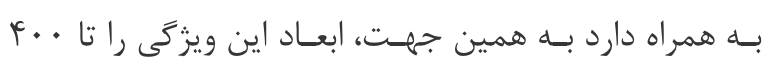
كاهش داده و به جاى كل ويزگگ ها استفاده مىشود. براى كاهش ويزگگى با اســتفاده از SVD ابتدا ماتريس

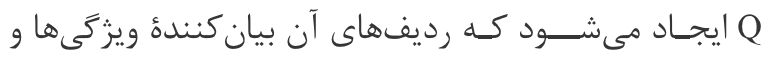

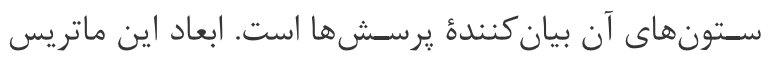

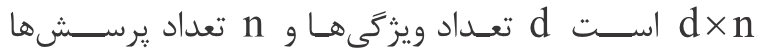
مىباشـد. هر عضو همانند

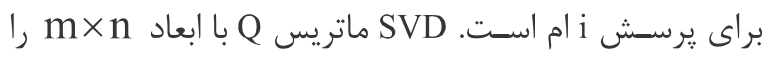
بـه ســــه مـاتريس م بوده و $U=\left[u_{i j}\right]$ سـتونهاى آن بردارهاى يكه سـمت جٍ ناميده مىشـوند؛ $S=\operatorname{diagonal}\left(\sigma_{1}, \sigma_{2}, \ldots, \sigma_{n}\right)$ اسـت كه عناصر قطر اصلى آن مقادير يكه غيرمنفى $m \times n$

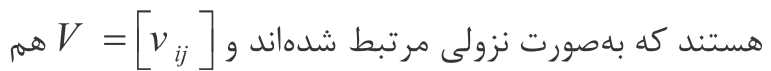

${ }^{1}$ Orthonormal 
انتخاب كليد اصـلى مربوط به يرســش، به اسـامى اولويت

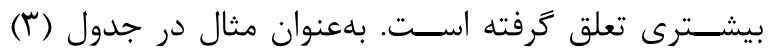
مجموعة اين قوانين ارائه شده است.

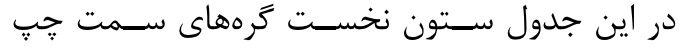

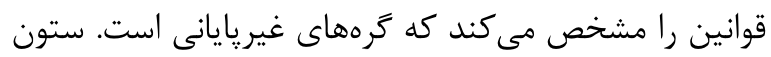
دوم جهت جستجوى سمت راست قوانين را مشخص مى كند.

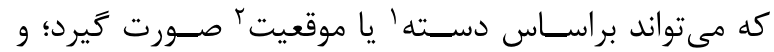
ستون سوم فهرست اولويت را بيان مى كند منظور از left by category ،L-b-C اسـت كه كه بيان مى كند از جֶٍترين فرزند، به ترتيب عكس فهرسـت الولويت عمل جستجو انجام مىشود و بروز هر تناظرى بهعنوان كليد

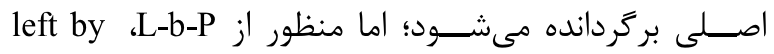

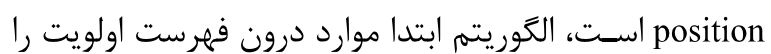
كنترل و تناظر اين موارد در فرزندان را از جٍ به به راسـت

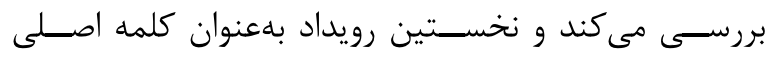

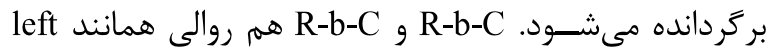
دارند؛ اما عمليات در سمت عكس موارد قبلى اجرا مىشود. اين قوانين، قوانين اصـلاحشده Collins است كه براى اعمال اين قوانين نياز اسـت درخت تجزيؤ يرسـش توسيط تجزيه روى درخت تجزيه اعمال مىشود.

اما قوانين ايجادشده براى همأ حالات نتيجة صحيحى

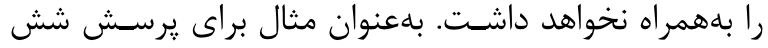

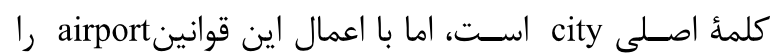

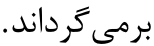

\section{Q6: What city is Logan Airport in?}

براى رفع اين مشـكل مىتوان قوانينى را بهعنوان استثنا قبل

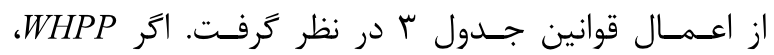
WHADVP، WHNP يا WHADJP بيش از يك فرزند داشته باشـد، اسهم يا كروه اسمى درون عبارت بهعنوان كلمة اصلى انتخاب شـود. كه در اين حالت نتيجة انتخاب كلمؤ اصـلى ديلى صحيح خواهد بود. ابعاد هر يك از ويزگى ها بهتفكيك نوع آن در جدول ^ آ آورده

\section{ب-ه - تركيب دسته بندها}

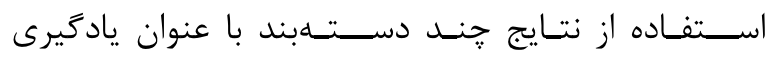
دستهجمعى، يك رويكرد مؤثر در يادكيرى ماشينى است كه در آن بلمنظور بهبود دقت ياد

${ }^{2}$ Position
اسـتخراج كلمهٔ اصـلى از يرسـش يكى از هالشهاى مهمم مىباشــ، اسـتخراج كلمهٔ اصـلى با اسـتفاده از سـاختار نحوى يرسـش اسـتخراج مىشود، براى اين منظور از درخت تجزيه يرسش استفاده مىشود.

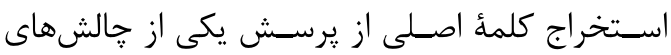
مههم مىباشــ، اسـتخراج كلمهٔ اصـلى با اسـتفاده از سـاختار نحوى يرسـش اسـتخراج مىشود، براى اين منظور از درخت تجزيه يرسش استفاده مىشود. نخسـتينبار ايده اسـتخراج كلمهٔ اصـلى از ســاختار درخت تجزيه توسط Collins در [2] ارائه شد. در [2] تعدادى

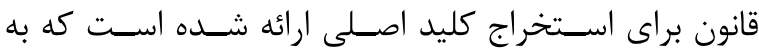
قانونهاى Collins شناخته مىشوند.

(جدول-r): قوانين استخراج كليد اصلى [11]

(Table-3): Primary key extraction rules [11]

\begin{tabular}{|l|l|l|}
\hline Parent & Direction & Priority List \\
\hline ROOT & L-b-C & S, SBARQ \\
\hline S & L-b-C & VP, FRAG, SBAR, ADJP \\
\hline SBARQ & L-b-C & $\begin{array}{l}\text { SQ, S, SINV, SBARQ, } \\
\text { FRAG }\end{array}$ \\
\hline SQ & L-b-C & NP, VP, SQ \\
\hline NP & R-b-P & $\begin{array}{l}\text { NP, NN, NNP, NNPS, NNS, } \\
\text { NX }\end{array}$ \\
\hline PP & L-b-C & $\begin{array}{l}\text { WHNP, NP, WHADVP, } \\
\text { SBAR }\end{array}$ \\
\hline WHNP & L-b-C & $\begin{array}{l}\text { NP, NN, NNP, NNPS, NNS, } \\
\text { NX }\end{array}$ \\
\hline WHADVP & L-b-C & $\begin{array}{l}\text { NP, NN, NNP, NNPS, NNS, } \\
\text { NX }\end{array}$ \\
\hline WHPP & L-b-C & $\begin{array}{l}\text { NP, NN, NNP, NNPS, NNS, } \\
\text { NX }\end{array}$ \\
\hline VP & R-b-C & $\begin{array}{l}\text { WHNP, WHADVP, NP, } \\
\text { SBAR }\end{array}$ \\
\hline SINV & L-b-C NN, NNP, NNPS, NNS, & NX, SQ, PP \\
\hline NX & L-b-C & $\begin{array}{l}\text { NP, NN, NNP, NNPS, NNS, } \\
\text { NX, S }\end{array}$ \\
\hline
\end{tabular}

در يـك قـاعـدة كرامرى آزاد از بـافـت بهصـورت غ $X \rightarrow Y_{1} \ldots Y_{2}$ غير يايانى هسـتند، قواعد اصـلى مشــص مى كنـند كه كدام

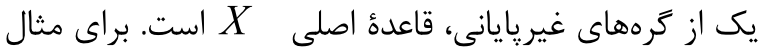
بـراى دسـتـور كـARQ مشـخص مى كنند كه كلمةٔ اصـلى در گرهٔ غيريايانى Collins قرار دارد. اين روال بهصــورت تكرارشــونده تا زمان رسيدن به كرة پايانى ادامه مى يابد. در [11]، [18] و [7] مجموعه قوانين براى اسـتخراج

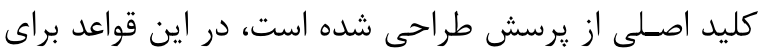

Category 


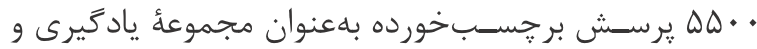
يانصـد يرسش برجسب خرورده بهعنوان مجموعه آزمون است.

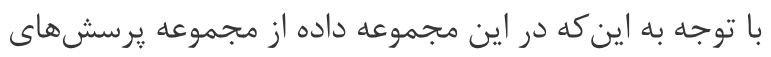

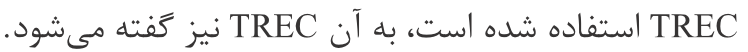

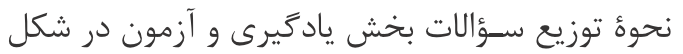

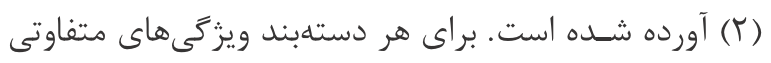

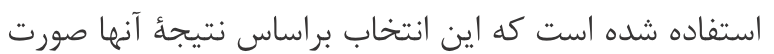
كرفته است.

(جدول - ه): نتايج حاصل از دستهبندها براى ويثگ هـى ماى متفاوت (Table-5): Classifiers result on different features

\begin{tabular}{|c|c|c|c|c|c|}
\hline $\mathrm{U}$ & $\mathrm{H}$ & $\begin{array}{c}\mathrm{H}- \\
\text { WS }\end{array}$ & $\begin{array}{c}\text { H-WS- } \\
\text { LB }\end{array}$ & $\begin{array}{c}\text { WH-H- } \\
\text { WS-LB }\end{array}$ & \\
\hline 82.2 & 68.3 & 72.6 & 90 & 92.2 & svm \\
\hline 91.2 & 66.4 & 68.6 & 87.5 & 88.3 & src \\
\hline
\end{tabular}

آزمايش بالا بر روى دادههاى آموزش با k-fold=10 اجرا شده

براى دستهبند مبتنى بر ماشين بردار يشتيبان بهترين

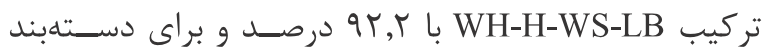
مبتنى بر نمايش يراكنده r, 19 اسـت، بنابراين از تركيب دو دسـتهبند با ويثزى هاى يادشده عمليات دستهبندى رئر را اعمال مى كنيم. نتايج حاصل از دستهبندها براى هريك از دستهها در جدول (9) (9) (9 آوده شده است. با توجه اطلاعات جدول مىتوان نتيجه گرفت روش

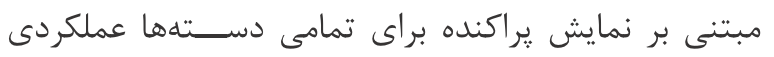

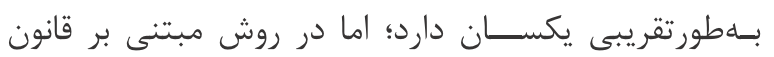

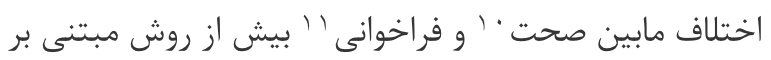
نمايش يراكنده اسـت و اين بهعلت نحوه اعمال قوانين است،

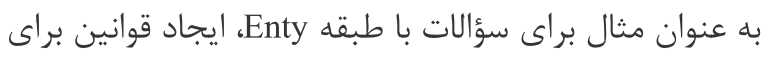
اين دسـته به جهت نوع و سـاختار يرسـشها بهدليل بروز اسـتثناهاى فراوان مشكل است. به همين جهت در ساختار و ترتيب قوانين مشـخص كردن اين دسـته در انتها قرار زرفته اسـت و در عدم تطابق قيرسـش با هيج يك از قوانين، به اين

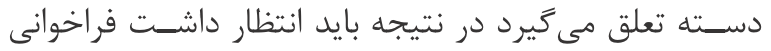
مربوط به اين دسـته زياد، اما صسحت آن كم باشـد كه نتايج حاصله اين موضوع را تأييد مى كند.

\footnotetext{
${ }^{7}$ Decision Template

${ }^{8}$ Dempster-Shafer Combination

${ }^{9} \mathrm{https}: / /$ gate.ac.uk/

${ }^{10}$ precision

${ }^{11}$ recall
}

يكديكر تركيب شـده و يك سـامانه مركب شــل مى گيرد. خروجى الكوريتمهــاى مختلف دســتـهبنــى در يكى از شكلهاى زير بيان مىشود [5].

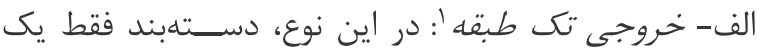
برجسب طبقهاى، براى الكوى ورودى ارائه مى كند.

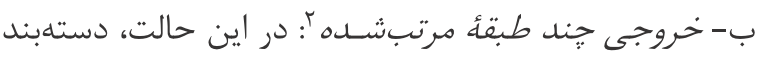

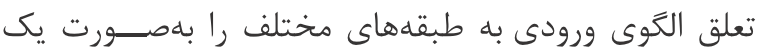
فهرســت مرتـب ارائه مى كند. طبقه با بيشترين تعلق در ابتداى فهرسـت و طبقه با كمترين تعلق در انتهاى آن قرار

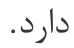

(جدول - F) : تعداد ابعاد ويثزى هاى استخر اجى

(Table-4): the number of extracted features dimensions

\begin{tabular}{|c|c|c|c|c|c|}
\hline H-W & L-B & W-W & W-S & Unigrams & \\
\hline 1964 & 1010 & 8 & 5 & 9775 & نوع لغوى لغوى \\
\hline
\end{tabular}

ج- خروجى جند طبقع /متيازدارّا: در اين شـكل، دســنهبند براى تعلق الكَى ورودى به هر كدام از طبقهها يك مقدار عددى تخصــيص مىدهد. اين مقدار عددى بيانَّر ميزان

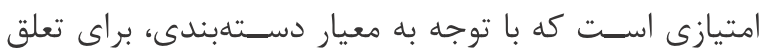
الكوى ورودى به آن طبقه محاسبه شده است. متــاولترين تقســـيمبندى براى روشهاى تركيب

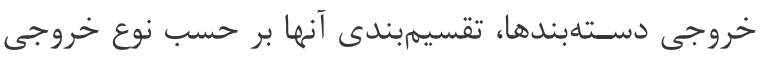
الكوريتهم دسـتهبندى است كه بر اساس آن روشهاى تركيب به ســه دسـته تقسـيم مىشوند. خروجى دستهبندهاى مورد اسـتفاده تكىطبقه هسـتند به اين جهت از روشهاى تركيبى

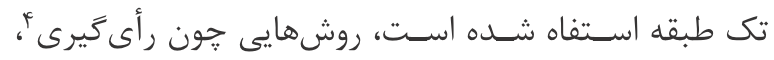

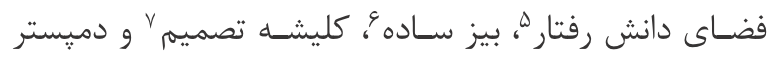
شفر ^ كه نتايج هر يك در بخش بعد آورده شده است.

\section{F - Pيادهسازى و ارزيابى}

براى ابزارهاى يردازش زبان طبيعى مورد اسـتفاده (تجزيهَر،

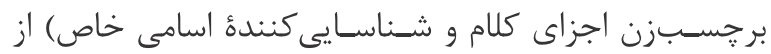
ابزار دانشـعاه اسـتنفورد [3] ، [12] و [20]. و همجٍنين براى Gazetteer

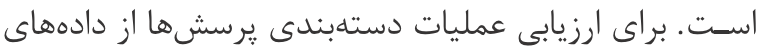
اسـتاندار UIUC اسـتفاده شـده اسـت، اين مجموعه شـامل

\footnotetext{
${ }^{1}$ Abstract level

${ }^{2}$ Rank level

${ }^{3}$ Measurement level

${ }^{4}$ Voting

${ }^{5}$ Behavior knowledge space

${ }^{6}$ Naive Bayes
} 
با توجه به نتايج شـكل (זّ)، امتياز F1 مربوط به SR

براى ســه دسـتـ دسـتهبند مبتنى بر قاعدهABBR و در انتها روش مبتنى بر بـهـتــــ SVM و DESC سـادهترين حالت، اگر دستهبندها به گَونهاى تركيب شوند كه براى هر دسـته از يرسـشها، با توجه به نتايج بيان شـده، از

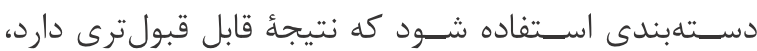
تركيب سامانهها ثمربخش خواهد بود.

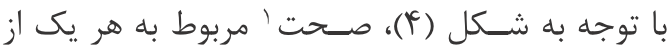

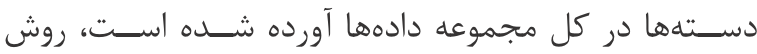

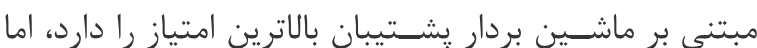

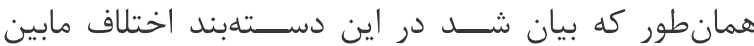
دسـتههاى يرسـشها زياد است و با اصلاح نتايج اين دستهها مى توان به نتايج بهترى دست يافت.

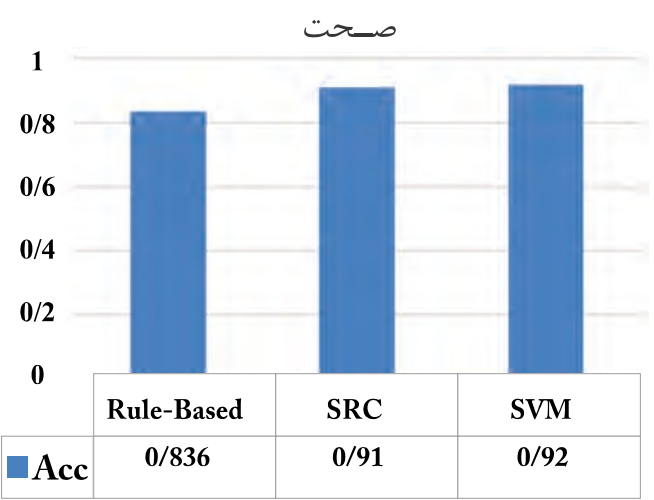

(شكل- (\$): امتياز صحت

(Figure-4): Accuracy Score
يرسشهاى UIUC

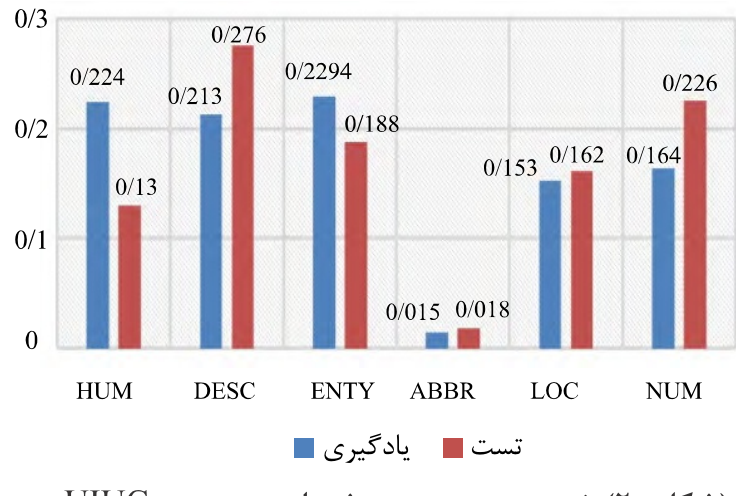

(شكل - r): نسبت برجسب يرسش هاى موجود در UIUC (Figure-2): The UIUC questions tag ratio

همجنين دقت دســتهبند مبتنى بر قانون براى بعضسىى از

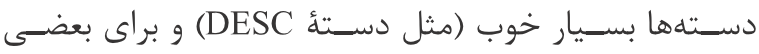
دستهها، نتيجهُ قابل قبولى به همراه ندارد. (ABBR)

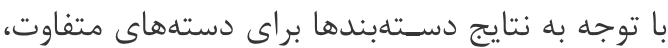
مىتوان انتظار داشت، نتيجه حاصل از تركيب اين دستهبندها نتيجهُ قابل قبول و بهتر از هر يك از دســـهبندها بهصـورت جدا شود.

F1 Score

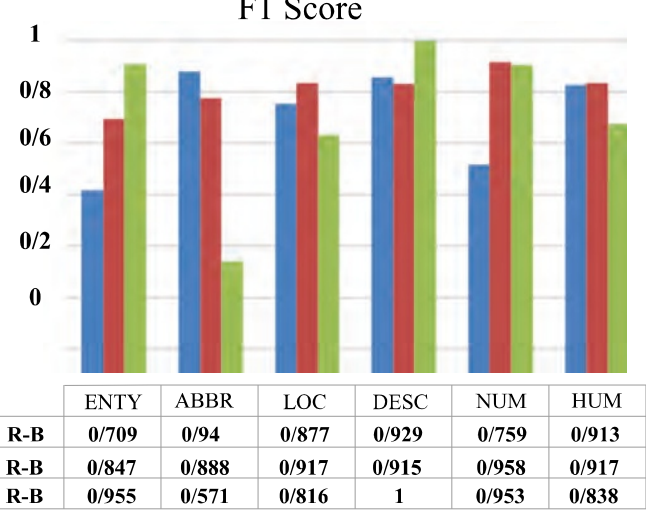

(شكل - r): نتايج دستهبند مبتنى بر نمايش قانون، SVM و SRC

(Figure-3): The results from SRC, SVM and the Rule-based classifier

(جدول - 9): نتايج حاصل از دستهبندها براى ويزَكىهاى متفاوت

(Table-6): Classifiers results on different features

\begin{tabular}{|c|c|c|c|c|c|c|c|c|c|c|c|c|}
\hline & & & NUM & $\% D$ & ESC & & OC & $\% \mathrm{~A}$ & BBR & & NTY & دسته \\
\hline & & & & & & & & & & & & معيار \\
\hline 34 & 100 & 98 & 62 & 92 & 94 & 90 & 85 & 90 & 100 & 57 & 94 & Rule ba \\
\hline 93 & 89 & 92 & $\underline{100}$ & 94 & 89 & 88 & 94 & 88 & 88 & 86 & 83 & SRC \\
\hline 2 & 76 & 91 & $\underline{100}$ & 100 & 100 & 82 & 80 & 66 & 50 & 91 & 100 & svm \\
\hline
\end{tabular}


صـورت رخداد در مرحله يادگيرى برجســبى در نظر كرفته

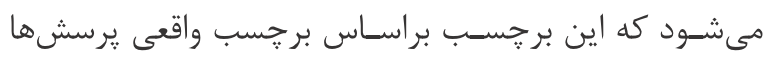
مىباشد[1]. در روش بيز سـاده ابتدا با توجه به دادههاى آموزشىى

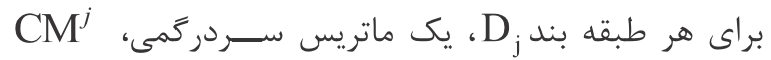

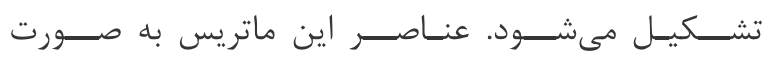
هستند. $\mathrm{CM}^{j}(\mathrm{k}, \mathrm{s})$ مقدار درايه CM, s) بيانگر تعداد الكوهايى اسـت كه برجسـب واقعى آنها k است، يعنى متعلق به طبقه

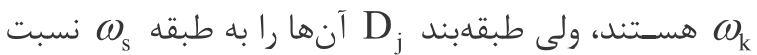

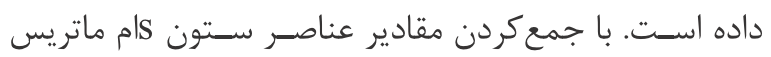

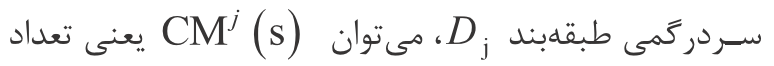
كل عناصرى كه اين طبقهبند به طبقه $\omega_{\text {S }}$ نسبت داده است

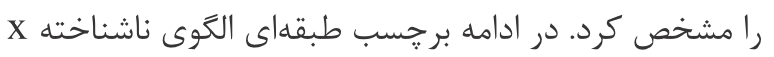

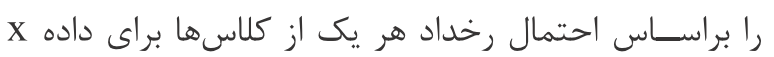

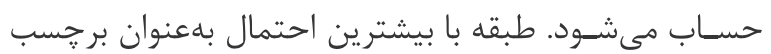

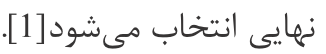
در روش كليشــه تصـميم در ابتدا با اسـتفاده از نمونهاى آموزشى

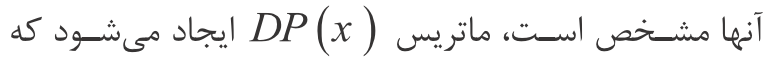

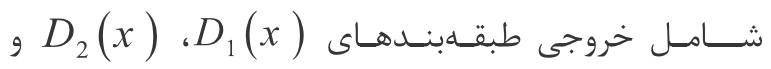
است. در ادامه ماتريسهايى كه مربوط به دادههاى $D_{3}(x)$

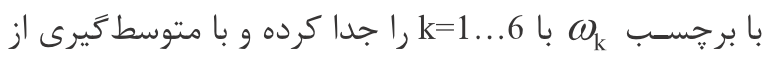
درايسهاى نظير به نظير ماتريسها، ماتريس

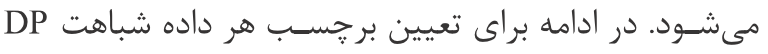

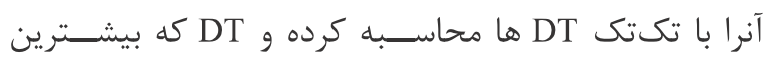

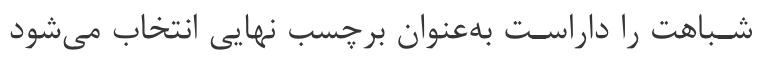

در روش تئورى دميستر شفر براى تركيب طبقهبندها،

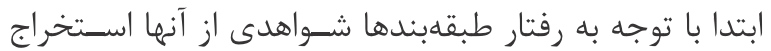

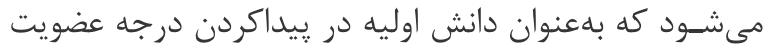

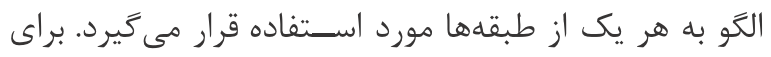

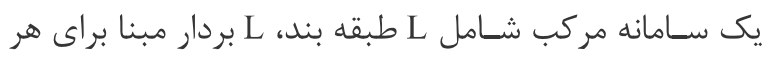

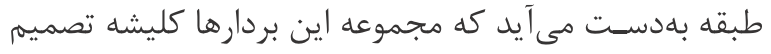

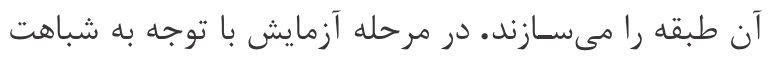

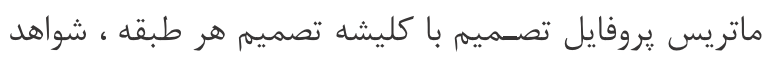
مورد نياز براى روش دميسـتر شفر بهدست آمده و ميزان باور و سرانجام درجه عضويت هر طبقه محاسبه مىشود. طبقه با بال بيشترين درجه عضويت، طبقه الكَى ورودى خواهد بود [1].
اسـتفاده از تركيب نتايج طبقهبند يكى از روشهاى

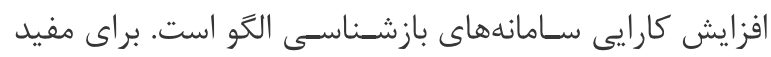

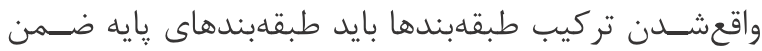
برخوردارى از كارايى قابل قبول، با يكديكر متفاوت بوده و قاعدة تركيبى مناسـبى براى تلفيق نتايج آنها بهار كار كرفته

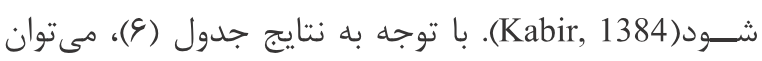
ادعا كرد هريك از دسـتهبندها بهتنهايى نتيجأ قابل قبولى

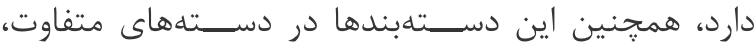

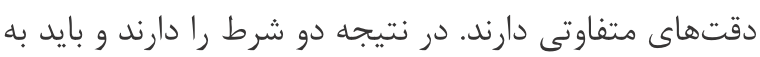
دنبال قاعدة تركيبى مناسب بود.

در روشهاى دســهبندى، بهالزام افزايش ويزگكىها با

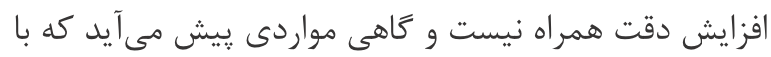

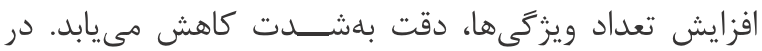

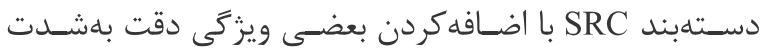

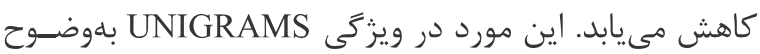
مشتصص است به جهت استفاده از ويزگكىهاى مناسب، جهت دسـتيافتن به دقت بيشــتر، هر مجموعه از ويزگكىها با دستهبندهاى متفاوت مورد استفاده قرار كرفته است تا ضمن دئن

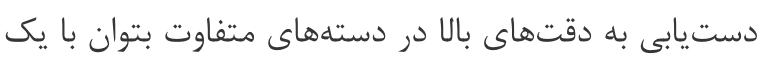
روش تركيبى مناسب دقت كلى را افزايش داد. همانطور كه اشاره شد، برجسب نهايى هر يرسش ازئ

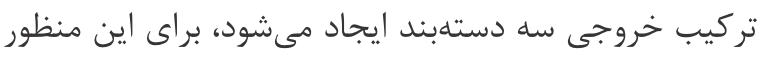

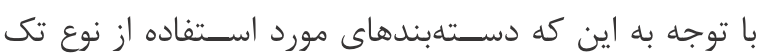

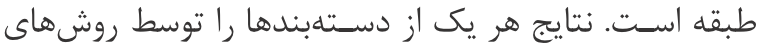

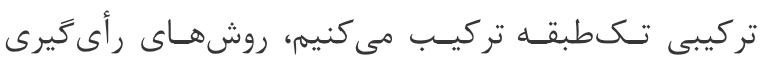

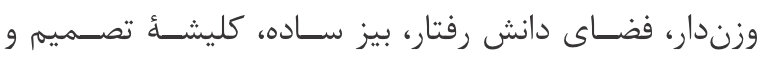

$$
\text { دميستر شفر. }
$$

در روش رأى گيرى وزندار، نياز اسـت براى هر دسته

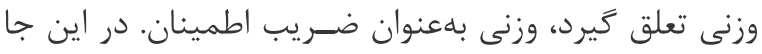
براى هر دستهبند، وزن تعلق كرفته يك، بردار ششتايى است كه همان صحت هر دستهبند براى شش دستأ موجود است.

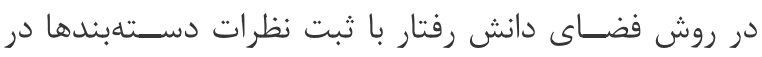

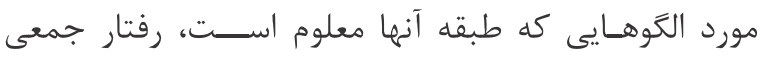
دسـتهبندها را مدل كرده و بر اسـاس اين مدل برجسـبـ

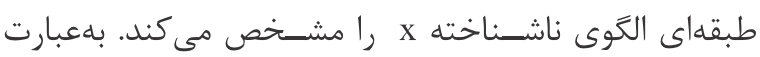

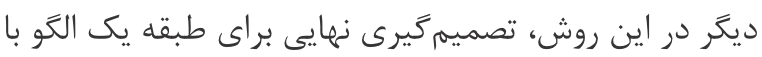

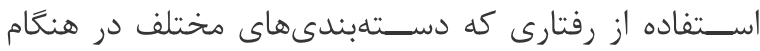

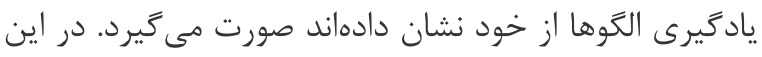
روش بايد تمامى حالات ممكن در نظر كرفته شـود. در اينجا

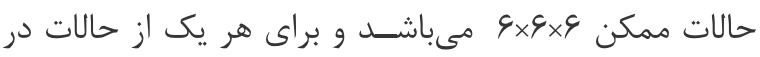


[5] T.K. Ho, J.J. Hull, and S.N. Srihari, "Combination of decisions by multiple classifiers." In Structured document image analysis, Springer Berlin Heidelberg 1992, pp. 188-202.

[6] Hoque, M. Moinul, T. Goncalves, and P. Quaresma, "Classifying Questions in Question Answering System Using Finite State Machines with a Simple Learning Approach." In PACLIC Vol. 27, Taiwan 2013 pp. $409-414$.

[7] Z. Huang, M. Thint, and Z. Qin, "Question classification using head words and their hypernyms." In Association for Computational Linguistics: Proceedings Conference on Empirical Methods in Natural Language Processing, Hawaii USA: ACL 2008, pp. 927-936.

[8] V. Krishnan, Das. Sujatha, and S. Chakrabarti, "Enhanced answer type inference from questions using sequential models." In Association for Computational Linguistics: Proceedings Conference on Empirical Methods in Natural Language Processing, Vancouver Canada: ACL 2005, pp. 315322.

[9] Kuncheva, I. Ludmila, Combining pattern classifiers: methods and algorithms. John Wiley \& Sons, 2004.

[10] Li, Xin, and D. Roth, "Learning question classifiers." In Association for Computational Linguistics: COLING '02 Proceedings of the 19th international conference on Computational linguistics, Taipei, Taiwan: COLING 2002, pp. 1-7.

[11] B. Loni, S. H. Khoshnevis, and P. Wiggers, "Latent semantic analysis for question classification with neural networks." In Automatic Speech Recognition and Understanding, Hilton Waikoloa: ASRU, 2011, pp. 437-447.

[12] M. C. Marneffe, B. MacCartney, and D. Christopher, "Generating typed dependency parses from phrase structure parses." In Conferences bring together a large number of people working and interested in HLT Proceedings: LREC, Genoa, Italy: May 2006, pp. 449454.

[13] A. Merkel, and D. Klakow, "Improved methods for language model based question classification." In INTERSPEECH, Antwerp, Belgium :August 2007, pp. 322-325.

[14] D. Moldovan, M. Paşca, S. Harabagiu, \& M. Surdeanu, "Performance issues and error analysis in an open-domain question answering system." ACM Transactions on Information Systems, vol. 21, pp. 133-154, October 2003.

[15] Y. Pan, Y. Tang, L. Lin, \& Y. Luo, "Question classification with semantic tree kernel." In ACM SIGIR conference on Research and development in information retrieval: Proceedings of the 31st annual international, Singapore, Singapore, July 2008, pp. 837-838.

[16] D. Radev, W. Fan, H. Qi, H. Wu, \& A.Grewal, "Probabilistic question answering on the

$$
\begin{aligned}
& \text { مواقعى كه دسـتهبند مبتنى بر ماشـين بردار يشتيبان نتيجهُ }
\end{aligned}
$$

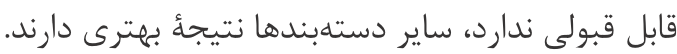

$$
\begin{aligned}
& \text { روشهاى مورد اســتفاده در اين مقاله براى تركيب }
\end{aligned}
$$

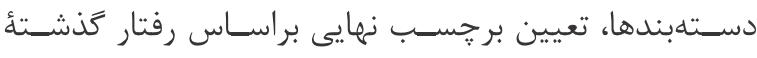

$$
\begin{aligned}
& \text { دستهبندها است. در واقع وضعيت كنونى داده در دستهبندها برها } \\
& \text { در نظر گرفته نمىشـود. ميىتوان با اسـتفاده از دستهبندهاى } \\
& \text { احتمالى مثل بيز و يا تبديل دستهبند مبتنى بر ماشين بردار }
\end{aligned}
$$

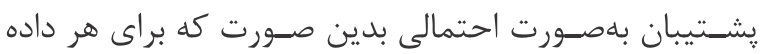

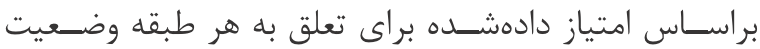

$$
\begin{aligned}
& \text { كنونى داده را در برجسب نهايى دخيل داد؛ علاوه بر اين براى } \\
& \text { دسـتهبندهاى مورد استفاده در اين مقاله از ويزگى هاى لغوى }
\end{aligned}
$$

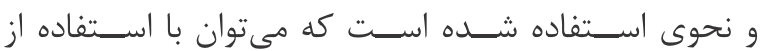

$$
\begin{aligned}
& \text { ويزگى هاى معنايى مثل زيرشـمولها يا مترادفات مربوط به }
\end{aligned}
$$

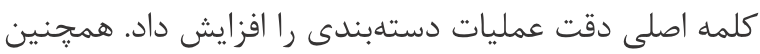

$$
\begin{aligned}
& \text { در اين مقاله براى دســتهبندى مبتنى بر يادگيرى از كرنل } \\
& \text { خطى اسـتفاده شـده اسـت. با توجه بـه كارهاى انجامشـده، } \\
& \text { بلويزه براى دســتهبندى مبتنى بر نمايش زيراكنده و نتايج }
\end{aligned}
$$

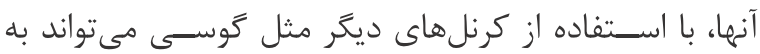

$$
\begin{aligned}
& \text { نتايج بهترى دست يافت. }
\end{aligned}
$$

\section{6-Reference}

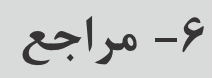

$$
\begin{aligned}
& \text { نبوى كريزى، سـيدحسن.، كبير، احسان اله،، "تركيب طبقه }
\end{aligned}
$$

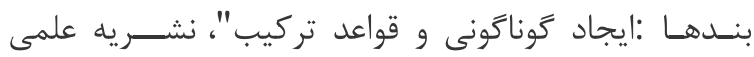

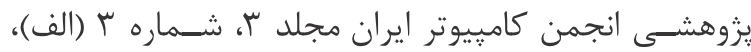

$$
\begin{aligned}
& \text { صفحه ه } 9 .
\end{aligned}
$$

[1] S.H. Nabavi karizi, \& E. Kabir, "Combining classifiers: Diversifying and rules of composition." CSI Journal on Computer Science and Engineering, vol. 3 , pp. 95 . Autumn 1384

[2] M. Collins, "Head-driven statistical models for natural language parsing." Computational linguistics, vol. 29, pp. 589-637, Dec 2003.

[3] J.R. Finkel, T. Grenager, and C. Manning, "Incorporating non-local information into information extraction systems by gibbs sampling," In Association for Computational Linguistics: Proceedings of the 43rd annual meeting on association for computational linguistics, Michigan: ACL, 2005. pp. 363-370.

[4] Ulf. Hermjakob, "Parsing and question classification for question answering," In Association for Computational Linguistics: Proceedings of the workshop on Open-domain question answering, Vol. 12, France: ACL, 2001, pp. 1-6. 


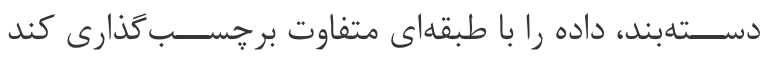

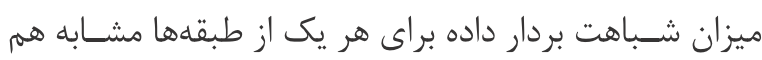

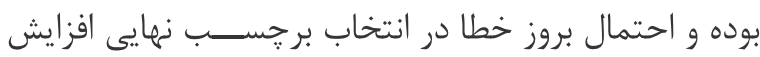

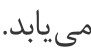

در روش تركيبى ارائهشــه، برجسـب نهايى براسـاس رفتار كذشـتـأ دستهبندها مشخص مىشود و وضعيت داده در

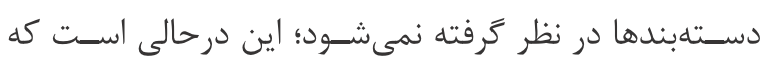
ممكن است برجسبدهى با اشتباه همراه باشد. بهعنوان مثال

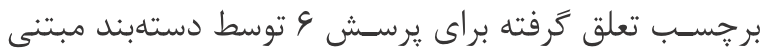

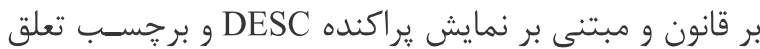

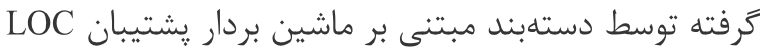

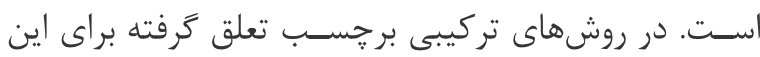
يرسـش DESC اسـت كه اين برجسـب به اشـتباه داده شده اسـت. در SVM متلب برجسـب دادهشده توسط تابع نشانه' در آخرين مرحله مشخص مىشود. درواقع براى مقادير كم و زياد به يك صـورت برخورد مى كند و يك برجسـب تعيين مىشـود. اين در صورتى است كه براى دادههاى با مقدار زياد

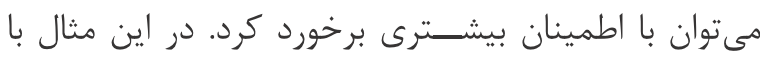

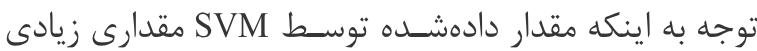

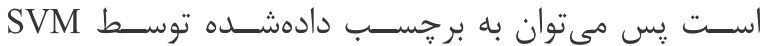

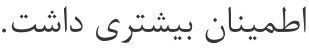

\section{ه- نتيجهَيرى و كارهاى آينده}

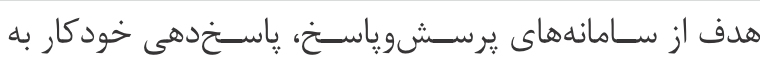
يرسـشهاى زبان طبيعى اسـت كه توسـط انسـان يرسـيده مىشود. در اين سامانها دستهبندى يرسشها نقان نقشى مهمم در انتخاب قاسـخ صحيح براى يرسـش داده شده دارد. در اين مقاله يك روش تركيبى جديد براى دسـتهبندى برسش بر ارائه

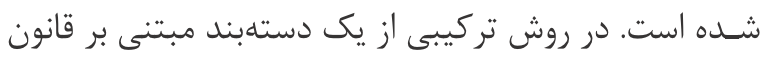
و دو دسـتهبند مبتنى بر يادگيرى اسـتفاده شـده است. براى

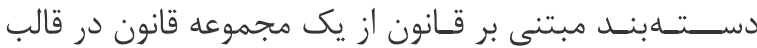
عبارات منظم استفاده شده است؛ و براى دستهبندهاى مبتنى بر يادكيرى عمليات دسـتهبندى براساس ويزگكىهاى لغوى و نحوى يرسشها انجام مى گيرد. براى تركيب نتايج دستهبندى از روشهاى رأى گيرى، بيز ساده و فضاى دانش رفتار استفاده شده است كه با روش تركيبى بيز ساده بهترين نتيجه حاصل

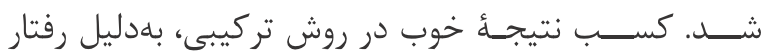
متفاوت دســتهبندها در روشهاى مختلف اســت. يعنى در
با توجه به نتايج حاصـل از شـكل ه نتايج حاصـل از

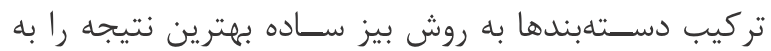

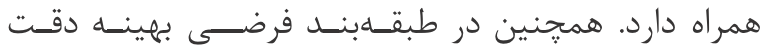

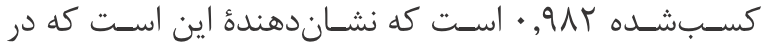
بهترين روش تركيبى مورد اسـتفاده كه بيز سـاده اسـت، به اندازه و • ., • خطا وجود دارد؛ جون كه طبقهبند فرضى بهينه تنها زمانى اشـتباه مى كند كه همه طبقلهبندهاى يايه اشـتباه كنند. يِ اين اختلاف بيان كنندة اين نكته اسـت كه حداقل يكى از دستهبندها عمليات برجسب تذارى رائ را بهدرستى انجام داده است؛ اما در تركيب نتايج سامانه دهار اشكال شده است. در روش تركيبى فضـاى دانش رفتار علت קايينبودن نتيجه وجود حالتهاى بدون نتيجه اسـت. حالتهايى كه در

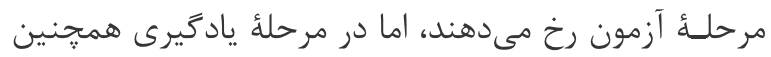

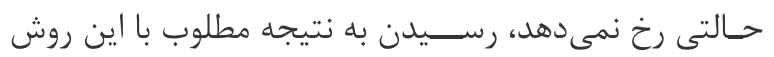

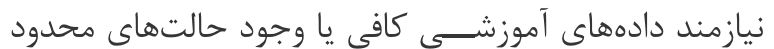

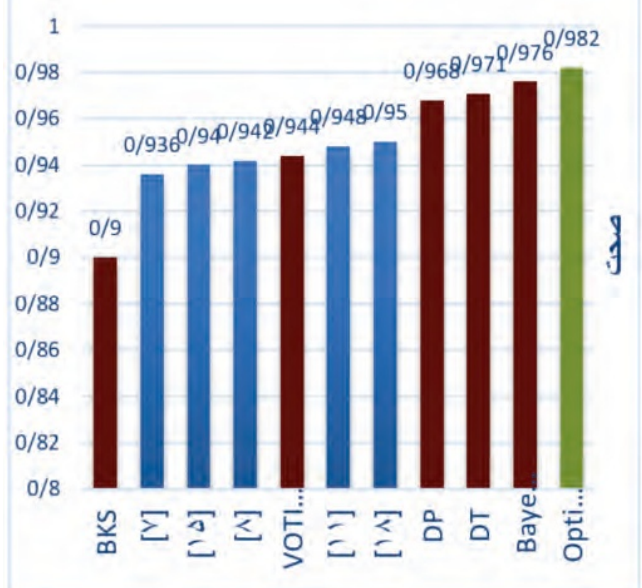

(شكل-ه):امتياز نهايبى سيستم و سيستمهاى موجود

(Figure-5): The final score from the proposed method and the other existing approaches

روش تركيسب وزندار تنهـا بسه وضـعيت همان داده

وابسـته است. خالش اصلى اين روش تركيبى در حالتى است كه تعداد بيشترى از دستهبندها بهاشتباه يك طبقه را را انتخاب

كنند كه سبب اشتباه در برجسب تذارى نهايى مى دود. درسـتى روشهاى كليشـأ تصسميهم و تئورى دميستر

شـفر وابسـته به وضعيت دادههاى مرحله آزمون است و براى دئي طبقههاى با تعداد دادة كمتر احتمال بروز خطا بيشـتر است. علاوه بر اين در اين دو روش در حالتهايى كه هر يك از سه

${ }^{1}$ sign 
web," Journal of the American Society for Information Science and Technology, vol. 56, pp. 571583, DEC 2005.

[17] S. K. Ray, S. Singh, \& B. P. Joshi, "A semantic approach for question classification using WordNet and Wikipedia." Pattern Recognition Letters, vol. 31, pp. 1935-1943, October 2010

[18] J. Silva, L.Coheur, A. C. Mendes, \& A. Wichert, "From symbolic to sub-symbolic information in question classification." Artificial Intelligence Review, vol. 35, pp. 137-154, February 2011.

[19] H. Sundblad, "Question classification in question answering systems". Phd dissertation,. Institutionen för datavetenskap, 2007.

[20] K. Toutanova, D. Klein, C.D. Manning, \& Y. Singer, "Feature-rich part-of-speech tagging with a cyclic dependency network". In Association for Computational Linguistics on Human Language Technology: Proceedings of the Conference of the North American Chapter, Washington, DC, USA, October 2003, pp. 173-180.

[21] J. Wright, et al. "Robust face recognition via sparse representation." IEEE transactions on pattern analysis and machine intelligence, vol 31, pp. 210-227, Feb 2009.

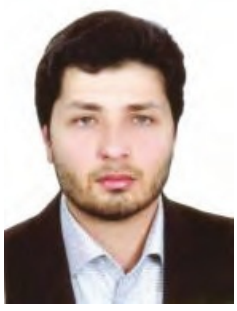

$$
\begin{aligned}
& \text { هادى قائمى مدرك كارشناسى ارشد } \\
& \text { خود را در رشته مهندسى كامييوتر } \\
& \text { گرايش هوش مصنوعى از دانشعاه } \\
& \text { فردوسى مشهد اخذ كرده است. زمينه } \\
& \text { يزوهشى مورد علاقه ايشان شامل يردازش } \\
& \text { زبان طبيعى و يردازش الگو است. } \\
& \text { نشانى رايانامئ ايشان عبارت است ازئ ئردئ }
\end{aligned}
$$

\section{Hadi.qaemi@stu.um.ac.ir}

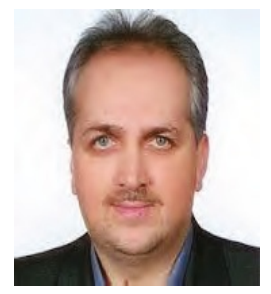

كاهانى استاد گروه مهندسى

كامِيوتر دانشگاه فردوسى مشهر و مدير

آزمايشگاه فناورى وب است. ايشان

دكتراى خود را در رشته مهندسى

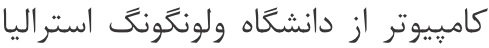

در سال ITVV اخذ كرده است. زمينه يثزوهشى مورد علاقه ايشان شامل وب معنايى، يردازش زبان طبيعى، سيستمهاى تصميم يار و مهرندسى نرمافزار است.

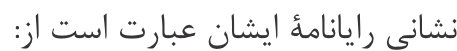

kahani@um.ac.ir 
